\title{
Nursing actions in human milk banks in times of COVID-19
}

\author{
Ações da enfermagem nos bancos de leite humano em tempos de COVID-19 \\ Acciones de la enfermería en los bancos de leche humana en tiempos de COVID-19
}

Giovanna Rosario Soanno Marchiori' ORCID: 0000-0002-0498-5172

Valdecyr Herdy Alves' ORCID: 0000-0001-8671-5063

Audrey Vidal Pereira ORCID: 0000-0002-6570-9016

Bianca Dargam Gomes Vieira' ORCID: 0000-0002-0734-3685

Diego Pereira Rodrigues" ORCID: 0000-0001-8383-7663

Paolla Amorim Malheiros Dulfe ORCID: 0000-0003-1653-4640

Marcia Vieira dos Santos ORCID: 0000-0002-1488-7314

'Universidade Federal Fluminense. Niterói, Rio de Janeiro, Brazil. "Universidade Federal do Pará. Belém, Pará, Brazil.

How to cite this article: Marchiori GRS, Alves VH, Pereira AV, Vieira BDG, Rodrigues DP, Dulfe PAM, Santos MV. Nursing actions in human milk banks in times of COVID-19. Rev Bras Enferm. 2020; 73(Suppl 2):e2020 0381. doi: http://dx.doi.org/10.1590/0034-7167-2020-0381

Corresponding author Giovanna Rosario Soanno Marchiori E-mail: giovannamarchiori@id.uff.br

EDITOR IN CHIEF: Dulce Barbosa ASSOCIATE EDITOR: Fátima Helena Espírito Santo

Submission: 04-30-2020

Approval: 08-22-2020

\section{ABSTRACT}

Objective: To analyze the actions of the Human Milk Banks coordination to favor the continuity of breastfeeding in the COVID-19 pandemic. Methods: Descriptive study, of qualitative approach, with theoretical-methodological reference of Pierre Bourdieu. Data collection was done through interviews between March and April, with five coordinations and results organized by thematic analysis. Results: Two categories were produced: the actions of strategies for the maintenance of Human Milk Banks services by digital means as a way to ensure social distancing and breastfeeding in times of pandemic of the new coronavirus; and the actions of promotion, protection and support in strategies for maintenance of breastfeeding during the pandemic. Final considerations: The benefits of breastfeeding outweigh any potential risks of transmission of the new coronavirus. The importance of systematic nursing practices in the quality and safety of the process of Protection, Promotion and Support of Breastfeeding is evident.

Descriptors: Milk Banks; Betacoronavirus; Coronavirus Infections; Breastfeeding; Nursing.

\section{RESUMO}

Objetivo: Analisar as ações das coordenações dos Bancos de Leite Humano para favorecer a continuidade da amamentação na pandemia da COVID-19. Métodos: Estudo descritivo, de abordagem qualitativa, com referencial teórico-metodológico de Pierre Bourdieu. Coleta de dados por entrevista entre março e abril, com cinco coordenações e resultados organizados por análise temática. Resultados: Foram produzidas duas categorias: As ações de estratégias da manutenção dos serviços do Bancos de Leite Humano por meios digitais como forma de garantir o distanciamento social e a amamentação, em tempos de pandemia do novo coronavírus; e as ações de promoção, proteção e apoio nas estratégias de manutenção da amamentação durante a pandemia. Considerações finais: Os benefícios da amamentação superam quaisquer riscos potenciais de transmissão do novo coronavírus. Evidencia-se a importância de práticas de enfermagem sistematizadas na qualidade e segurança do processo de Proteção, Promoção e Apoio ao Aleitamento Materno.

Descritores: Bancos de Leite; Betacoronavírus; Infecções por Coronavírus; Aleitamento Materno; Enfermagem.

\section{RESUMEN}

Objetivo: Analizar las acciones de las coordinaciones de los Bancos de Leche Humana para favorecer la continuidad del amamantamiento en la pandemia de COVID-19. Métodos: Estudio descriptivo, de abordaje cualitativo, con referencial teórico-metodológico de Pierre Bourdieu. Recogida de datos por entrevista entre marzo y abril, con cinco coordinaciones y resultados organizados por análisis temático. Resultados: Han producidas dos categorías: Las acciones de estrategias de la manutención de los servicios del Bancos de Leche Humana por medios digitales como manera de garantizar el distanciamiento social y el amamantamiento, en tiempos de la pandemia del nuevo coronavirus; y las acciones de promoción, protección y apoyo en las estrategias de manutención del amamantamiento durante la pandemia. Consideraciones finales: Los beneficios del amamantamiento supieron cualesquier riesgos potenciales de transmisión del nuevo coronavirus. Se evidencia la importancia de prácticas de enfermería sistematizadas en la calidad y seguridad del proceso de Protección, Promoción y Apoyo a la Lactancia Materna.

Descriptores: Bancos de Leche; Betacoronavirus; Infecciones por Coronavirus; Lactancia Materna; Enfermería. 


\section{INTRODUCTION}

The Human Milk Banks (HMB) have been configured as one of the most important strategic elements of public policy in favor of breastfeeding. As it is a specialized service, its actions aim at the Promotion, Protection and Support of Breastfeeding (PPS) ${ }^{(1)}$. Currently, the actions of the HMB were directly affected by the COVID-19 pandemic, caused by the new coronavirus called SARS-CoV-2. Initially, when it appeared in Asia (China) (2), In December 2019, there was no record of the severity of the disease and its possible impacts on world health.

The World Health Organization (WHO) $)^{(3)}$ made an announcement on March 11, 2020 that the world was suffering from a pandemic due to the new coronavirus. SARS-CoV-2 is an agent related to respiratory infections, which can present a similar picture to other flu syndromes. The transmission of the virus, based on scientific knowledge acquired so far, occurs through its entry into the respiratory tract ${ }^{(4)}$.

To prevent transmission, the adoption of some behavioral measures is recommended ${ }^{(4)}$, however a Brazilian study ${ }^{(5)}$ indicates that certain measures of social isolation and distance must take into account social aspects and beliefs of the population. For this type of virus, no vaccine is available yet. In view of this scenario, the protective measures of the federal government, recommended by the $\mathrm{WHO}^{(6)}$, consist of social estrangement, quarantine and social isolation of the infected.

In this context, until the moment of this research, there were no studies that related this virus to pregnancy or brought information if, in the breastfeeding process, the infected mother could transmit it to the newborn baby. With the advance of infection and its spread to other continents, as well as the increase in the number of cases, pregnant women, women in labor and women who have recently given birth have become part of the risk group, and breastfeeding has demanded differentiated attention ${ }^{(7)}$. However, the available scientific evidence indicates that there is no evidence of this vulnerability, except for the physiological transformations arising from pregnancy ${ }^{(8)}$.

In order to promote breastfeeding, the procedures at HMB required adaptations to the dynamics of its operation, in the clinical management practices performed by nurses and other professionals, aiming to collaborate with the containment measures through social distancing to preserve the health of women, newborns, their families and health professionals ${ }^{(9)}$.

Therefore, this work has, as its investigative question, to ask what are the strategies mobilized in the confrontation of the pandemic, for the maintenance of breastfeeding in times of social distancing.

\section{OBJECTIVE}

To analyze the actions of the Human Milk Banks coordinations, to favor the continuity of breastfeeding in the COVID-19 pandemic.

\section{METHODS}

\section{Ethical aspects}

The study was approved by the Research Ethics Committee of the Fluminense Federal University School of Medicine, following the ethical principles contained in the Resolution $n^{\circ} 466 / 12$ of the National Health Council ${ }^{(10)}$.

\section{Theoretical-methodological reference}

The research used the concept of habitus as theoretical and methodological support in the discussion of the data. For Bourdieu, habitus materializes in the way society becomes deposited in people in the form of durable dispositions or trained capacities and structured propensities to think, feel and act in determined ways ${ }^{(11-12)}$.

\section{Type of study}

Descriptive, exploratory, qualitative approach study ${ }^{(13)}$, with the purpose of capturing nursing actions in BLH in the context of social distance.

\section{Methodological procedures}

\section{Study scenario}

The research was conducted through the HMB coordination of public hospitals of the unique Health System of Rio de Janeiro and Espírito Santo: Antônio Pedro University Hospital in Niterói/ RJ; Sugarcane Planter's Hospital in Campos de Goytacazes/RJ; Adão Pereira Nunes State Hospital in Duque de Caxias/RJ; São João Batista Hospital in Volta Redonda/RJ; and Cassiano Antônio Moraes University Hospital in Vitória/ES.

$\mathrm{HMB}$ is a service for women, children and families to attend to the demands and inter-currencies related to the promotion, protection and support of breastfeeding. The focus of this care is based on the Resolution of the Collegiate Board of Directors (RCBD) No. 171, September 4, 2006, of the National Health Surveillance Agency (Anvisa), which determines the rules for the operation of $\mathrm{HMB}^{(14)}$ and compliance with their Technical Standards (TS) and manuals ${ }^{(15)}$.

\section{Data source}

The study participants were three HMB and nursing coordinators and two HMB coordinators (one biologist and one nutritionist). As inclusion criteria: to be HMB coordinator; to maintain the interface with the nursing coordination and interdisciplinary work process and/or nursing team coordinator. The exclusion criterion consisted in being away from HMB services (care, collection and processing of breast milk, home visit, support groups to the binomial, with free demands from the UHS and private network) because of belonging to the risk group of the COVID-19 pandemic or because of being on vacation.

The approaches with the coordinators were made by telephone, due to the social distancing recommended at the national level. Therefore, because it was a survey using a phone call or messages by the WhatsApp application, the consent form was replaced by the verbal consent obtained when contacting the interviewees.

\section{Data collection and organization}

The data collection technique used was a telephone interview, consisting of open questions regarding the strategies and measures 
adopted by the HMB to maintain breastfeeding continuity during the times of COVID-19. The questions that guided the interview were: How is the action to promote breastfeeding being carried out in times of protective measures? How does HMB work on breastfeeding protection in social isolation? What measures has $\mathrm{HMB}$ implemented to offer or maintain breastfeeding support? What are the strategies to face the pandemic, maintain social distance and breastfeeding in this scenario? The speeches provided in audio call or message per application were transcribed in full, for later production and data analysis. In order to guarantee the confidentiality of the information, an alphanumeric code was used $(\mathrm{C} 1 \ldots \mathrm{C}$ ).

\section{Data analysis}

The data was worked on according to the analysis of content in the thematic modality ${ }^{(16)}$. Thus, the analysis was carried out in three phases: pre-analysis; exploration of the material; and treatment of results, inferences and interpretation. After the identification of the registration units, they founded the construction of the thematic unit that indicated the design of the following thematic categories: 1) The actions of strategies for the maintenance of HMB services by digital means, as a way to ensure social distance in a period of global dissemination of the new coronavirus; and 2 ) the actions to promote, protect and support breastfeeding maintenance strategies in times of pandemic of COVID-19.

\section{RESULTS}

\section{The actions of Human Milk Banks's services maintenance strategies by digital means as a way to ensure social dis- tancing and breastfeeding in times of pandemic of the new coronavirus}

Issues related to the management and planning of short, medium and long term actions to face the pandemic and maintain breastfeeding were identified, as well as the strategies found by the $\mathrm{HMB}$ coordination, in dialogue with nursing supervision, in view of the changes and impacts on social behavior and interpersonal relations caused by COVID-19. In addition, the intensification of the fields of action for other intersectoral environments and external to the HMB is evident, with the proper maintenance of services by digital means as a way to guarantee, in times of COVID 19 , social distancing and breastfeeding.

Regarding planning, management, interventions and nursing assistance, the statements indicate that there was exclusive planning to meet short-term demands, maintenance of internal basic services, intensification of telephone service and adaptation to support and promotion of breastfeeding through other means of communication:

We are also sending via WhatsApp our guidance and care brochures and milking, donation etc. We have not closed the service, we have reorganized ourselves in face of the new context. [...] We have suspended other non-emergency activities. (C1)

All these actions are accompanied by changes and impacts on social behavior and interpersonal relationships. The statements indicate that the social distancing measures required as a strategy to contain the spread of the new coronavirus challenged the HMB team and established adjustments in breastfeeding protection and support practices:

We are trying to preserve as much as possible the practice of breastfeeding! Although I understand that the studies have shown some questions regarding COVID-19, right? And the mothers who had babies, who are with the disease, how does this isolation have to be done? [...] for me, in my experiencel had no case, lexperienced absolutely nothing, I only know in theory. (C2)

One of the actions that has demanded alteration and overcoming of this distance corresponds to the service of domiciliary collection of human milk donations and collection of donors. It is necessary to reinforce the guidelines contained in HMB-IFF / NT19.11 (Transport of milked milk). In those HMBs where the home collection services occurred with the displacement of the nurturers to the institution, there was the need for interruption and the search for alternatives. In view of the recommendation for people not to leave home, the coordination is counting on the families and a team for external work. This capture is important mainly to maintain the care in the Neonatal Intensive Care Unit (NICU). To manage the circulation of people and avoid transmission, both those who are willing to donate and those who come into contact with the team, a logistics is mobilized, as can be seen in the narrative:

Entry to the milk bank is restricted only to mothers of NICU. These women who are at home with difficulty in breastfeeding, unfortunately at the moment we are not able to attend, even for the safety of these mothers, these children, not to encourage these people to be leaving home. (C3)

With the orientation of social distance and to avoid group activities, some HMBs compensate their PPS actions and, therefore, move their team to intensify the actions in hospital units. The face-to-face actions were directed to the maternity ward, the joint lodgings and the NICUs, a sector that can be considered the most affected by this distance and by the difficulty in attracting donors. At the same time as the internal demands, the HMB professionals started to attend in a remote way; and, in case of emergency, a nursing attendance is scheduled.

In this moment of social distancing, nursing has assumed a preponderant role to maintain the works of promotion and incentive to breastfeeding, with prominence to the joint lodgings of the maternity wards, as observed in the speech:

I am the nurse responsible for mother and child. So, anyway, I, as coordinator also of the Milk Bank here, end up guiding these women. [...] I, as a nurse, as a breastfeeding consultant, answer with my [Facebook] page, so that we can try to clear up some doubts, give some guidance. (C3)

The demands arrive by telephone or through the social networks of the interviewees, besides the internal attendance. The guidance and hospitality provide the need both for questions of clinical management of breastfeeding, the rights of the pregnant 
woman and the difficulty in breastfeeding, as well as those related to COVID-19, since it becomes another problem to deal with when guiding a mother with suspected infection or a donor. In this care, breastfeeding needs to be guaranteed with extra care, even if at a distance:

They have been calling us, and as it is forbidden to enter, I have been answering by phone or [...] at any moment I will receive a call from a woman who is having problems. I talked to her to make an audio later. [...] We're working by phone, we continue with the route, not in the home visit itself. (C2)

Faced with the changes caused by the pandemic, actions and strategies to maintain the HMB's services by digital means emerge as a way to guarantee, in times of COVID-19, social distancing and breastfeeding. The telephone is adopted as a tool to bring the $\mathrm{HMB}$ team closer to the public served, a solution to maintain the work. Strategies include: video referrals, WhatsApp messaging, text messaging, Internet referrals through websites ( $\mathrm{rBLH}$, YouTube, Telessala, Instagram, Facebook, links and others), as seen in speech:

We are only exploring a little this support through telephone, through video calls. l even prefer it to be by video on the phone [...]. I was using the computer and I'm using some little films [videos] that you have on YouTube, right? And I ask her to access, so I can clear up some doubts. (C1)

In times of the new coronavirus pandemic, digital breastfeeding care practices were adopted to overcome barriers, innovating care and attention practices to the mother-baby binomial. In some cases, it is necessary to break the social distance, move forward and face the problem:

[It is necessary to use the digital media] ... in clinical cases of non-reverted breast ingurgitation, mastitis, breast trauma with unbearable pain, weight loss of the infant, and other causes that telephone guidance does not address. (C1)

From the testimonials, it appears that the work ceases to be on demand and requires scheduling, prior call and evaluation case by case, with the exception of one of the HMBs researched, which kept all services running until the time of completion of this investigation. In the interviewee's speech, the phone number was always available and there was no change:

We have an SOS phone for people who need some help or clarification regarding breastfeeding, as well as specific care or urgencies related to breastfeeding. This number has not changed, it is the same and continues to answer, with a reduction in demand in person. (C4)

It is understood that nursing assistance, in the case of patients with suspicion or confirmation of COVID-19, has required new arrangements and the use of Personal Protective Equipment (PPE), previously required according to technical standard BLHIFF / NT15.20 (Biosecurity in Human Milk Banks and Collection Posts) and also cited in BLH-IFF / NT11.20 (Hygiene and Conduct: Employees); today, they are preponderant and imperative to safeguard lives at this time of pandemic and uncertainty.

\section{Actions to promote, protect and support breastfeeding} maintenance strategies in times of COVID-19 pandemic

The PPS practices were adapted to the social reality and to the transformations of people's routines, both of collaborators and of the public served in the HMBs. The actions of incentive and awareness programs on human milk donation, the provision of assistance to pregnant women, babies who have recently given birth, nurturers and infants in the practice of breastfeeding, as well as the processing and quality control of human milk milked, required adaptations, maintaining the necessary scientific rigor and attention to biosafety standards.

The talks also revealed different social actors (family members and friends who maintain an affective bond with their families) in the struggle for continued breastfeeding care. The families are fundamental in PPS's breastfeeding actions, collaborating in the process of collection and distribution of milked milk, in the logistics of maintaining the NICU's stocks, and in complying with the rules imposed at this time of the pandemic, as can be seen in this fragment:

I register by phone, we get the data from the internet, the exam data, everything else and then the driver goes to the patient's house, leaves at the reception, usually the PPEs, the bottles and then we set a date, usually the same day of the following week to return. (C2)

The exam data are regulated by RDC 171/2006 and do not determine any extra exam of the patient, in accordance with BLH-IFF / NT- 09.11 (Donors: Screening, Selection and Follow-up and the Recommendation Human Milk Donation). However, in the COVID-19 pandemic, there is an obligation to track possible asymptomatic or pre-symptomatic cases, in addition to noting confirmed cases so that necessary measures can be taken to avoid contagion from nursing staff and other HMB users.

Regarding PPS actions and maintenance strategies of breastfeeding in times of COVID-19 pandemic, it is understood that the administration of the service in the HMB was greatly impacted. The participants of this study talk about the promotion of breastfeeding, and there is a fight in defense of breastfeeding, in the midst of the fight against the new coronavirus. The promotion of breastfeeding and the fight against the pandemic are articulated, as evidenced in the action plan of the HMB coordinators:

Today I worked all day on the issue of breastfeeding promotion, [...] the HMB commission itself was asking us to make a recording to forward [...], to be able to make the announcement on the network. We keep passing on the message [...] embedded in this promotion, right? [...], embedded in this attempt to serve this woman, right?! [...] of her rights, you know??! (C2)

The planned actions include guidance at hospital discharge, education and guidance with the first care of babies, from avoiding the use of complements (formulas), pacifier, bottle to providing the necessary conditions for the mother to exercise the right to breastfeed her child in different spaces and public environments. A speech indicates the continuity of these actions:

I don't really observe any change in the question of breastfeeding protection, I think that the laws are still the same, right? There has 
not been any kind of change, women, they lose access to health services for guidance and support to breastfeeding. [...] although I understand that the studies have been showing some issues related to COVID-19, right?! (C2)

The support actions, which consist of support to the pregnant woman in the delivery room to perform the breastfeeding action in the first hour of the newborn's life, emotional support to the woman for breastfeeding, clinical management actions and care guidance after discharge from hospital are the most affected by the COVID-19 pandemic. The social distance and barriers to physical contact established at this historical moment make it difficult to practice clinical breast evaluation, correction of baby handles and other procedures related to human milk milking. In the testimonies, the use of digital means to help in the support actions is perceived:

When the mothers leave, in some conditions that we realize they will have a problem, I pass the phone to them because I know that by the time she leaves, she will not be able to return. (C2)

Of the five HMBs researched, one kept the "doors open" and so far has not affected the actions of PPS, keeping the monitoring for the new coronavirus. At the other extreme, COVID-19 directly interfered in the functioning and dynamics of the HMB, observed in the lines:

The service follows normal, the use of PPE continues to be required as always for everyone. (C4)

Our municipality had a growing number of COVID-19 and many people are coming from the large centers to seek help here, needed to attend planning meetings with the hospital staff. (C5)

\section{DISCUSSION}

In a survey in the Virtual Health Library (VHL) on research published in the last five years, conducted on April 1, 2020, using the descriptors "Milk Banks" and "Breastfeeding", it was found that there are few productions that specifically address the issue of PPS. This theme was explicitly addressed in two studies ${ }^{(17-18)}$. However, such actions are present in several works that discuss the actions of nurses in $\mathrm{HMBs}^{(19-21)}$, the organization of practices in $\mathrm{HMB}$, the Brazilian Network of $\mathrm{HMB}^{(21-22)}$ and the donors' perceptions about the importance of the actions carried out in the $\mathrm{HMBs}^{(23)}$, but in a diffuse or implied manner.

In the strategy actions of the maintenance of the HMB services, the attention of the actions in times of pandemic of COVID-19 is focused on the orientation, protection, fulfillment of internal demands and support at a distance in the issues related to breastfeeding. It is noticeable that the medium and long term plans are being structured via HMB Network ${ }^{(24)}$. The first meeting took place on 03/16/2020, with the title"Breastfeeding in times of COVID 19 Epidemic"; and the second, on 03/23/2020, on "Good Practices in Belo Horizonte", also focusing on the pandemic ${ }^{(25)}$.

The breastfeeding orientation is an action within the policy of promoting breastfeeding, a strategy that seeks to raise awareness in society of the advantages of breastfeeding for mother, child and family as an option in feeding their children ${ }^{(18)}$. At this historic moment, this action has demanded efforts from authorities to promote breastfeeding in the face of evidence that the new coronavirus has made victims in all age groups, including newborns. The attention of public authorities is focused on the fight against the new coronavirus, and it is up to the coordination of the HMBs to seek mechanisms to strengthen the promotion of breastfeeding as a barrier to another disease.

Promotional actions, especially the encouragement of breastfeeding, actions to motivate and clarify the importance of milk for the mother-baby binomial, the maintenance of services to the community internally and externally, and the dissemination of the benefits of breastfeeding have been interfered with by the pandemic, since the attention of health authorities has been directed to combating the new coronavirus.

As for protection, the laws that guarantee the right to breastfeeding, women's health care and the assurance to children of their food security continue to be in force in times of pandemic; and, in the authors' view ${ }^{(18)}$, "the protection of breastfeeding can be harmed when performed in a deficient, reticent way, without clarity in its applicability". Protecting breastfeeding implies, among other things, guaranteeing the right to maternity/paternity leave, labor laws and the legal and protective issues of exclusive breastfeeding up to six months of life and its maintenance until two years of age ${ }^{(26)}$. Continuity is a decision of the mother and her family core.

In PPS actions and strategies to maintain HMB services, there is a lack of public policies to reinforce breastfeeding promotion at the expense of combating the pandemic. The women interviewed pointed out that they used electronic media, used leaflets and folders during the internal care, in the wards and maternity hospitals, taking advantage of the hospital discharge moment to clarify the rights and benefits of breastfeeding.

Virtual care was a strategy found to maintain support to the external public and guide as to clinical management in breastfeeding and care with the transmission of the new coronavirus. For this, the concept of habitus refers to nursing care, the adjustments in the ways of care in dialogue with the history of nursing and incorporation of new technologies, maintaining the theoretical basis that sustains their actions at any time ${ }^{(12)}$.

The strategy actions of maintaining HMB's services by digital means as a way to ensure social distancing and breastfeeding in times of the new coronavirus have demonstrated effectiveness in actions and short-term planning. It is evaluated that emergency measures were taken to maintain internal care and, when possible, comply with technical standards ${ }^{(15)}$ of collecting existing human milk donations. Information technologies by digital means were mobilized to soften social distance and bring patients closer to the services available in the HMBs. In addition, internal actions were strengthened, especially on the issue of donor intake, as the pandemic reduced human milk stocks and there was an imminent shortage to care for newborns in the NICU.

So far there is little literature available to discuss COVID 19 and breastfeeding. It is noted the record of a shared work in the complementary short note on COVID-19 and Breastfeeding, issued by Corintio Mariani Neto ${ }^{(27)}$. The available clinical study on vertical transmission of the new coronavirus, performed with 
nine patients with pneumonia caused by SARS-CoV-2, indicated a negative test for the presence of the virus, concluding that the benefits of breastfeeding were superior to a possible vertical transmission.

In this note, there is an opinion from Chinese experts that contraindicated breastfeeding, since, in thesis, vertical transmission of the virus could occur. Studies on the virus in the milk of suspected or diagnosed mothers were recommended, and if tested negative, consumption by babies was allowed. Even the donation of breast milk should be evaluated, taking into account asymptomatic cases and possible transmission in the excreted milk, considering also the presence of the new coronavirus during a possible incubation period of the disease. In this case, the right to breastfeeding found echoes in the literature ${ }^{(28-29)}$.

With regard to the guidelines that are carried out by the HMB team, the focus continues to be on the care of breastfeeding, attention to the needs of the mother-baby binomial ${ }^{(30)}$, but added to the issues that remind us of the current context of the COVID-19 pandemic. In this case, the habits of nursing are taken from the set of practices and ideologies characteristic of its agents ${ }^{(11)}$, materialized in the ways of operating the demands of care in the HMB supported by the recommendations of the HMB Network, and of possession of the recommendations of the HMB Network, from the Technical Recommendation $n^{\circ} 01 / 20.170320$, regarding COVID-19 and Breastfeeding ${ }^{(31)}$.

Technical Note No. 5/2020 of the Ministry of Health (MH) ${ }^{(32)}$, in relation to the conducts for breast milk donation to HMBs and Human Milk Collection Posts (HMCP) in the context of the new coronavirus infection, recommends the donation of human milk only by healthy infants and without home contact with a person with influenza syndrome. This measure is part of the actions of the HMBs and HMCPs, responsible for guiding the candidates for the donation, according to the protocols of the $\mathrm{MH}$ and in attention to RDC No. 171/2006 ${ }^{(14)}$.

According to the United Nations Population Fund (UNFPA), one of the UN agencies, there is no evidence that SARS-CoV-2 can be transmitted by breast milk(8) ${ }^{(8)}$ These strategies adopted for the maintenance of HMB services corroborate PPS's perspective. The habitus has as function to account for the unity of style that links the practices and assets of its agents, a generator and unifying principle. There is always the imperative to adopt procedures to prevent and control the disease, especially the hygienization of hands and the use of masks during breastfeeding or milk removal. The encouragement, in this moment of social distancing, continues to occur, guaranteeing the right to information.

This study sheds light on the strategies and actions carried out by the coordination of HMB - based on interdisciplinarity, and/or nursing, in the space of HMB in times of COVID-19 - that could favor the continuity of breastfeeding. The use of digital resources and smartphone devices with the use of WhatsApp messaging application, as narrated by the participants, indicates a new organization of services provided in HMBs and the need for training for the use of these technologies. The actions of the nursing are organized through a historical process structuring the habitus present in the field of the HMB. It is understood that the HMB teams have always used telephone lines as support for breastfeeding. Historically, the Brazilian Network of Human Milk
Banks has used these lines since 1985. However, at this historical moment, this tool, added to the current technological resources, has enabled the maintenance of services in the HMBs.

Therefore, all the material produced for the COVID-19 confrontation can be catalogued in future researches and serve as reference for the HMB team. Future investigations with women who have been tested positive for the new coronavirus and who have breastfed may indicate the transmission of antibodies to their newborns, as advocated in the scientific literature ${ }^{(33)}$.

\section{Study limitations}

The limitation of the research consists in the lack of compelling studies on COVID-19, since its manifestation is recent in the world context and it works on the basis of limited evidence, available until now. New studies can help in the understanding of the developments of this disease and how it can affect breastfeeding.

\section{Contributions to the Nursing, Health or Public Policy area}

This study clarifies the strategies and actions carried out by the nursing coordination in the HMB space, in times of COVID-19, which, in our opinion, could favor the continuity of breastfeeding. The use of digital resources and smartphone devices, as narrated by the participants, indicates a new organization of the services provided at $\mathrm{HMB}$ and the need for training to use these technologies. The strategies for facing the pandemic and maintaining breastfeeding in times of distance and social isolation have shown an exacerbated dependence on inputs and personal safety devices (PPE) from abroad, i.e., the need to import this material has revealed a weakness in the health system. Thus, all the material produced for the COVID-19 can be catalogued in future researches and serve as reference both for the HMB team and for the target audience of this specialized space, expanding the working tools regarding the promotion, protection and support of breastfeeding.

\section{FINAL CONSIDERATIONS}

Considering that there is no distance from the historical fact and that we do not have clarity about the situation involving different social, political and economic contexts, in which a disease overturns the health systems and has been demanding protective actions of social detachment, one wonders: What does this moment teach us? What is the legacy of this experience for HMB? What practices can be incorporated as protocols for attending new cases of pandemic or public calamity? What actions and strategies by digital means will remain as breastfeeding care and support practices?

It is argued that the benefits of breastfeeding outweigh any potential risks of transmission of the new coronavirus through breast milk; and, as advocated in the promotion of breastfeeding, this is an important protection mechanism for the mother-baby binomial now and in the future. Since there is no scientific evidence on vertical transmission and it is a woman's right to choose to breastfeed and remain close to her child from birth, this study ratifies the benefits of breast milk as an exclusive food, even in times of pandemic.

About the analysis of the actions of the nursing coordination in the $\mathrm{HMBs}$ to favor the continuity of breastfeeding in times of pandemic 
of COVID-19, it is considered that the planning of short and medium term managed to minimize the impacts on the actions of the HB. The smartphone communication device is highlighted as an essential tool to overcome social distance and maintain the policy of PPS. Other digital tools, identified as videos, documentaries, audio recordings, photographic images, electronic informative texts, video conferencing, video calling and messaging applications such as WhatsApp have transformed the way you do health and have been able to maintain the continuity of breastfeeding practices and actions.

Thinking about habitus, in a time of pandemic, when modus operandi are shaken and social practices are altered by the dynamics of social detachment and isolation, calls for reflections on the strategies of social subjects in reconfiguring their actions. The adequacy of practices in $\mathrm{HMB}$, as well as of human milk donors, reveal these transformations and reconfigurations of the habitus. The common code is in the process of digital updating, with the incorporation of technologies mobilized in the PPS of breastfeeding to confront the COVID-19.
It is evident the importance of systematic nursing practices, which can manage the work process in the assistance field, as in the HMBs. This makes possible quality and safety in the process of PPS, notably in odd moments like this, of confrontation of the pandemic of COVID-19. The nursing professional must act within his professional autonomy to detect such problems, even in extreme conditions like nowadays.

The use of information and communication technologies is a rearrangement of the current reality, however it is necessary to know how to take advantage of these resources, making them contribute to meet the demands of $\mathrm{HMB}$ and the maintenance of breastfeeding. Finally, however, it must be taken into account that such technological tools mobilized do not replace human contact.

\section{AKNOWLEDGEMENT}

I would like to thank all the coordinators who participated in this survey at such a difficult time in times of pandemic.

\section{REFERENCES}

1. Ministério da Saúde (BR). Agência Nacional de Vigilância Sanitária. Banco de leite humano: funcionamento, prevenção e controle de riscos [Internet]. Brasília: ANVISA; 2008[cited 2020 Apr 17]. Available from: https://www20.anvisa.gov.br/segurancadopaciente/index.php/ publicacoes/item/banco-de-leite-humano-funcionamento-prevencao-e-controle-de-riscos

2. Wu F, Zhao S, Yu B, Chen YM, Wang W, Song ZG, et al. A new coronavirus associated with human respiratory disease in China. Nature. 2020;579(7798):265-9. doi: 10.1038/s41586-020-2008-3

3. World Health Organization (WHO). Coronavirus disease 2019 (COVID-19) Situation Report - 51[Internet]. Geneva: WHO; 2020 [cited 2020 Apr 20]. Available from: https://www.who.int/docs/default-source/coronaviruse/situation-reports/20200311-sitrep-51-covid-19. pdf?sfvrsn=1ba62e57_10

4. Ministério da Saúde (BR). Saúde anuncia orientações para evitar a disseminação do Coronavírus[Internet]. Brasília: Ministério da Saúde; 2020[cited 2020 Apr 21]. Available from: https://www.saude.gov.br/noticias/ agencia-saude/46540-saude-anuncia-orientacoes-para-evitar-a-disseminacao-do-coronavirus

5. Lima DLF, Dias AA, Rabelo RS, Cruz ID, Costa SC, Nigri FMN, et al. COVID-19 no Estado do Ceará: Comportamentos e crenças na chegada da pandemia. Cien Saude Colet [Internet]. 2020 [cited 2020 Apr 21]. Available from: http://www.cienciaesaudecoletiva.com.br/artigos/ covid19-no-estado-do-ceara-comportamentos-e-crencas-na-chegada-da-pandemia/17540?id=17540\&id=17540

6. Center for Disease Control and Prevention (CDC). Coronavirus Disease 2019 (COVID-19): social distancing, quarantine, and isolation [Internet]. Atlanta: CDC; 2020 [cited 2020 Apr 21]. Availablefrom: https://www.cdc.gov/coronavirus/2019-ncov/prevent-getting-sick/socialdistancing.html

7. Ministério da Saúde (BR). Boletim Epidemiológico Especial 07, 06/04/2020 [Internet]. Brasília: Ministério da Saúde; 2020[cited 2020 Apr 21]. Available from: https://portalarquivos.saude.gov.br/images/pdf/2020/April/14/Protocolo-de-Manejo-Cl--nico-para-o-Covid-19.pdf

8. Fundo de População das Nações Unidas (UNFPA). COVID-19: agências da ONU divulgam informações para mulheres grávidas; pedem recursos para crianças [Internet]. Brasil; 2020 [cited 2020 Apr 17]. Available from: https://nacoesunidas.org/ covid-19-agencias-da-onu-divulgam-informacoes-para-mulheres-gravidas-e-pedem-recursos-para-criancas/

9. Belasco AGS, Fonseca CD. Coronavírus 2020. Rev Bras Enferm. 2020;73(2):e2020n2. doi: 10.1590/0034-7167-2020730201

10. Ministério da Saúde (BR). Conselho Nacional de Saúde. Resolução n 466, de 12 de dezembro de 2012. Aprova as diretrizes e normas regulamentadoras de pesquisas envolvendo seres humanos e revoga as Resoluções CNS n 196/96, 303/2000 e 404/2008 [Internet]. Brasília: Ministério da Saúde; 2012 [cited 2020 Apr 21]. Available from: https://conselho.saude.gov.br/resolucoes/2012/Reso466.pdf

11. Bourdieu P. A economia das trocas simbólicas. São Paulo: Perspectiva; 2007.

12. Bourdieu P. Razões práticas: sobre a teoria da ação. Campinas: Papirus; 1996.

13. Minayo MCS. O desafio do conhecimento: pesquisa qualitativa em saúde. 14a ed. São Paulo: Hucitec; 2014.

14. Ministério da Saúde (BR). Resolução RDC/ANVISA no 171, de 4 de setembro de 2006. Dispõe sobre o regulamento Técnico para o funcionamento de Bancos de Leite Humano [Internet]. 2006[cited 2020 Apr 13]. Available from: http://www.redeblh.fiocruz.br/media/rdc_171.pdf

15. Rede Brasileira de Banco de Leite Humano (RBLH). Normas técnicas e manuais [Internet]. 2020 [cited 2020 Jun 30]. Available from: https:// rblh.fiocruz.br/normas-tecnicas-e-manuais 
Nursing actions in human milk banks in times of COVID-19 Marchiori GRS, Alves VH, Pereira AV, Vieira BDG, Rodrigues DP, Dulfe PAM, Santos MV.

16. Bardin L. Análise de conteúdo. Lisboa: Edições 70 LDA; 2011.

17. Branco MBLR, Alves VH, Rodrigues DP, Souza RDMP, Cruz AFDN, Marinho TF. Promoção do aleitamento materno nos bancos de leite humano do estado do Rio de Janeiro. Rev Enferm UFSM. 2015;5(3):434-43. doi: 10.5902/2179769216498

18. Branco MBL, Alves VH, Rodrigues DP, Souza RDMP, Oliveira Lopes F, Marinho TF. Proteção e apoio ao aleitamento materno: uma contribuição do banco de leite humano. Rev Pesqui Cuid Fundam. 2016;8(2):4300-12. doi: 10.9789/2175-5361.2016.v8i2.4300-4312

19. Crespo NCT, Santana RF, Alves VH, Pereira AV, Marchiori GRS, Rodrigues DP. Diagnósticos de enfermagem de mulheres nutrizes atendidas no Banco de leite humano. Enferm Foco. 2019;10(1):12-7. doi: 10.21675/2357-707X.2019.v10.n1.1396

20. Marchiori GRS, Alves VH, Rodrigues DP, Gabriel AD, Santos MV, Branco MBLR. Articulação entre sistematização de enfermagem e procedimentos operacionais: perspectiva dos enfermeiros dos bancos de leite. Rev Enferm UFSM. 2017; 7(2):179-92. doi: $10.5902 / 2179769225701$

21. Pereira JAC. Atuação do enfermeiro nos bancos de leite humano. Rev Enferm UFPE. 2017;11(7):2691-6. doi: 10.5205/ reuol.10939-97553-1-RV.1107201706

22. Barros MS, Almeida JAG, Rabuffetti AG. Rede Brasileira de Bancos de Leite Humano: uma rede baseada na confiança. RECIIS. 2018;12(2):12533. doi: $10.29397 /$ reciis.v12i2.1253

23. Marinho TF, Alves VH, Branco MBLR, Rodrigues DP, Mattos Pereira R, Marchiori GRS. Percepções valorativas de práticas em banco de leite humano. Cogitare Enferm. 2017;22(1):1-8. doi: 10.5380/ce.v22i1.48679

24. Rede Brasileira de Bancos de leite Humano (RBLH). rBLH enfrentando a COVID-19 [Internet]. 2020[cited 2020 Apr 13]. Available from: https:// rblh.fiocruz.br/rblh-enfrentando-covid-19

25. Rede Brasileira de Bancos de Leite Humano (RBLH). Reuniões Técnicas sobre Covid-19 [Internet]. 2020 [cited 2020 Apr 13]. Available from: https://rblh.fiocruz.br/reunioes-tecnicas-sobre-covid-19\#overlay-context=covid-19-e-amamentacao-recomendacao-n0120170320

26. Monteschio CAC, Gaíva MAM, Moreira MDS. The nurse faced with early weaning in child nursing consultations. Rev Bras Enferm. 2015;68(5):587-93. doi: 10.1590/0034-7167.2015680515i

27. Mariani Neto C. Nótula complementar sobre COVID-19 e Aleitamento Materno [Internet]. FEBRASGO, 11 Mar 2020[cited 2020 Apr 13]. Available from: https://www.febrasgo.org.br/pt/noticias/item/949-notula-complementar-sobre-covid-19-e-aleitamento-materno

28. Center for Disease Control and Prevention (CDC). Interim considerations for infection prevention and control of coronavirus disease (COVID-19) in Inpatient Obstetric Health Care Settings [Internet]. Atlanta; CDC. 2020[cited 2020 Apr 20]. Available from: https://www.cdc. gov/coronavirus/2019-ncov/hcp/inpatient-obstetric-healthcare-guidance.html

29. Royal College of Obstetricians and Gynaecologists (RCOG). Coronavirus (COVID-19) Infection in pregnancy. Information for health care professional[Internet]. 2020 [cited 2020 Apr 20]. Available from: https://www.rcog.org.uk/globalassets/documents/guidelines/coronaviruscovid-19-virus-infection-in-pregnancy-2020-03-09.pdf

30. Viduedo AFS, Leite JRC, Monteiro JCS, Reis MCG, Gomes-Sponholz FA. Severe lactational mastitis: particularities from admission. Rev Bras Enferm. 2015;68(6):806-11. doi: 10.1590/0034-7167.2015680617i

31. Rede Brasileira de Bancos de Leite Humano (RBLH). Recomendação técnica n. 01/20.170320. COVID-19 e Amamentação [Internet]. 2020 [cited 2020 Apr 13]. Available from: https://www.icict.fiocruz.br/sites/www.icict.fiocruz.br/files/rBlh_recomendacao_01020_170320.pdf

32. Ministério da Saúde (BR). Secretaria de Atenção Primária à Saúde. Nota técnica n 5/2020-COCAM/CGCIVI/DAPES/SAPS/ MS2020 [Internet]. 2020[cited 2020 Apr 13]. Available from: http://189.28.128.100/dab/docs/portaldab/documentos/ notatecnicaaleitamento30mar2020COVID-19.pdf

33. Palmeira P, Carneiro-Sampaio M. Immunology of breast milk. Rev Assoc Med Bras. 2016;62(6):584-93. doi: 10.1590/1806-9282.62.06.584 